DOI 10.15826/qr.2018.3.336

УДК 930(470)"19"+94(470)"19"

\title{
НАЦИЕСТРОИТЕЛЬСТВО ПО-СОВЕТСКИ*
}

Peu. на кн.: Yilmaz H. National Identities in Soviet Historiography : The Rise of Nations under Stalin. - L. ; NY : Routledge, 2015. - 240 p.

Виталий Тихонов

Институт российской истории РАН,

Москва, Россия

\section{NATION-BUILDING IN THE SOVIET WAY}

Rev. of: Yilmaz, H. (2015). National Identities in Soviet Historiography :

The Rise of Nations under Stalin. L., NY, Routledge. 240 p.

\author{
Vitaly Tikhonov \\ Institute of Russian History, \\ Russian Academy of Sciences \\ Moscow, Russia
}

The author reviews a monograph by $\mathrm{H}$. Yilmaz, the first attempt to synthesise data for the last half-century on the issue of Soviet nation-building: it demonstrates that in the 1930s-1940s, the Stalin regime purposefully formed historical narratives of the peoples of the USSR to lay foundations for their national identity. The author demonstrates that foreign policy played an important role in constructing the necessary historical narratives, especially the fear that neighbouring countries could use some nations for their own purposes. The most important reason for the intensive construction of the Soviet version of Ukraine's national history was Nazi Germany's desire to prove the historical inferiority of Slavic peoples. The book pays special attention to the formation of a new pantheon of national heroes and their use by Soviet propaganda to stimulate patriotic mobilisation during the Great Patriotic War. According to H. Yilmaz, no universal pattern was used to create national histories. For instance, the national histories

* Citation: Tikhonov, V. (2018). Nation-building in the Soviet Way. In Quaestio Rossica, Vol. 6, № 3, p. 912-919. DOI 10.15826/qr.2018.3.336.

Цитирование: Tikhonov V. Nation-building in the Soviet Way // Quaestio Rossica. Vol. 6. 2018. № 3. P. 912-919. DOI 10.15826/qr.2018.3.336 / Тихонов В. Нациестроительство по-советски // Quaestio Rossica. Т. 6. 2018. № 3. C. 912-919. DOI 10.15826/qr.2018.3.336.

(C) Тихонов В., 2018

Quaestio Rossica • Vol. 6 • 2018 • № 3, p. 912-919 
of Azerbaijan and Ukraine had more national romantic features than the Kazakh historical narrative. Thus, the process behind the writing of national histories was not one-sided compliance with the orders of the Soviet centre. National histories were authored by local historians controlled by local elites actively involved in nation-building. The book emphasises the fact that that images of the past created during the Stalin era still have a significant influence on the modern identity of the citizens of the post-Soviet republics.

Keywords: H. Yilmaz; national identity; Soviet historiography; nation-building; national history.

Представлена рецензия на монографию Х. Йылмаза - первую обобщающую работу по данной проблеме за последние полвека, где демонстрируется, что сталинский режим в 1930-1940-е гг. целенаправленно формировал исторические нарративы народов СССР для становления основы национальной идентичности. Показано, что значительную роль в конструировании нужных исторических нарративов играл внешнеполитический фактор, особенно опасение, что соседние державы могут использовать те или иные нации в своих интересах. Важнейшей причиной активного конструирования советской версии национальной истории Украины стало стремление нацистской Германии обосновать историческую неполноценность славянских народов. Особое внимание в книге уделяется формированию нового пантеона национальных героев и их использованию советской пропагандой для патриотической мобилизации в годы Великой Отечественной войны. По наблюдениям Х. Йылмаза, национальные истории создавались не по единому шаблону. Истории азербайджанские и украинские имели более выраженные национально-романтические черты, чем казахский исторический нарратив. Процесс создания национальных историй - не одностороннее исполнение директив из союзного центра. Истории писались в основном местными историками под контролем местных элит, которые принимали самое деятельное участие в нациестроительстве. В книге подчеркивается, что созданные в сталинское время образы прошлого все еще оказывают заметное влияние на современную идентичность жителей бывших советских республик.

Ключевые слова: Х. Йылмаз; национальная идентичность; советская историография; нациестроительство; национальная история.

Книга Х. Йлммаза посвящена процессу формирования новой национальной истории в 1930-1940-е гг. в советских республиках - Азербайджане, Украине и Казахстане. Интерес исследователей к национальным проблемам в сталинскую эпоху не ослабевает. Несмотря на обилие литературы по данной проблематике, монография историка из Великобритании Харуна Йылмаза (Harun Yilmaz) обязательно вызовет интерес специалистов, что обусловлено не только качеством исследования, но и не совсем обычным подходом, сочетающим в себе историю исто- 
рической науки и анализ механизмов нациестроительства сталинской эпохи, важнейшим элементом которых стало конструирование нового исторического сознания в союзных республиках.

К проблеме роли исторических образов в национальной политике сталинской эпохи уже обращались ${ }^{1}$. Примером является фундаментальный труд американского историка Л. Тиллет (1969). Данная работа долгое время являлась единственной обобщающей по заявленной проблематике [Tillett]. Однако автор не мог использовать советские архивы, что не позволило полноценно проанализировать механизм создания национальных историй. После распада Советского Союза появился ряд исследований, освещавших эти процессы в отдельных советских республиках. Написанные на основе архивных документов, они не претендуют на общесоюзный охват [Лінднэр; Yekelchyk]. Появление исследования, в котором давалась бы панорамная картина эволюции советских «национальных историй», вполне назрело.

Книга Харуна Йылмаза состоит из восьми глав, посвященных формированию новой национальной истории в 1930-е гг. и в годы Великой Отечественной войны в советских республиках - Азербайджане, Казахстане и на Украине. Работа построена на солидном источниковом фундаменте с привлечением российских и национальных архивов. Автор уделяет основное внимание механизмам и формам конструирования нужного сталинской власти образа прошлого народов. Главную мысль своей книги исследователь формулирует во введении: «Сталинское государство не только строило железные дороги, каналы и металлургические комбинаты, но и конструировало национальные идентичности с историческими нарративами» (с. 1)2. Созданные в сталинское время образы прошлого все еще оказывают заметное влияние на современную идентичность жителей бывших советских республик.

Автор признает, что случай сталинского Советского Союза, где история стала основой утверждения национальных идентичностей, вполне вписывается в общемировые тенденции. Но все же специфика Советского государства вытекала из его тоталитарной сущности (с. 5). Сталин видел в истории важнейший ресурс для утверждения своего культа и при этом проводил гибкую идеологическую политику, менявшуюся в зависимости от внутренних и внешнеполитических вызовов.

Крутой поворот в сталинской исторической политике автор по сложившейся историографической традиции начинает с 1934 г., когда на смену нигилистической в отношении наций «школе М. Н. Покровского» пришли новые стандарты историописания, оказавшиеся ближе к «романтическим национальным нарративам, чем интернационалистской марксистской классовой борьбе» (с. 8). Своего рода парадигмой

\footnotetext{
${ }^{1}$ См. рецензию на книгу А. И. Миллера «Нация, или Могущество мифа» (СПб., 2016) [Бут].

2 Здесь и далее ссылки на рецензируемое издание даются в круглых скобках с указанием страниц.
} 
для интерпретации истории взаимоотношений русского народа и всех остальных стала формула, объявлявшая присоединение нерусских народов к Российскому государству «наименьшим злом» в сравнении с тем, что было бы, если бы они вошли в состав менее прогрессивных (или более реакционных) государств. Здесь сразу же хотелось бы обговорить, что эта формула, прозвучавшая в отношении Украины и Грузии в «Замечаниях по поводу конспекта учебника по истории СССР» И. Сталина, А. Жданова и С. Кирова (август 1934 г.), отнюдь не сразу стала универсальным концептом. Вплоть до начала 1950-х гг. шли споры о возможности ее применения в отношении других народов и республик Советского Союза, и читатель находит это уточнение (с. 76).

Йылмаз считает, что главную роль в формировании новых национальных историй играли внешнеполитические факторы (с. 11). Исследователь учитывал не только глобальную мировую ситуацию (противостояние с капиталистическими странами, приход к власти нацистов и т. д.), но и влияние региональных игроков - Польши, Ирана, Турции, которые выдвигали или потенциально могли выдвинуть претензии на национальные территории СССР.

Первая глава The construction of Azerbaijani identity under the shadow of Iran and Turkey («Конструирование азербайджанской идентичности в тени Ирана и Турции») посвящена роли исторических нарративов в формировании азербайджанцев как советской нации. Делается это в контексте аналогичных процессов в Турции и Иране. Автор указывает, что до 1937 г. азербайджанцы в советских документах назывались «турками» (с. 19). В 1920-е гг. Азербайджан играл роль кавказской витрины советского проекта, демонстрируя достижения коммунистической власти в реализации прав нации. Но в 1937 г. Первый секретарь ЦК Коммунистической партии Азербайджана М. Багиров заявил, что одной из главных опасностей для СССР является пантюркизм, исходящий из Турции. Не менее сложными стали и отношения с Ираном, где проживала большая часть этнических азербайджанцев. Политика «осажденной крепости» оказалась стимулом для формирования новой идентичности народов республики, отличной от тюркской или иранской. В этом заметную роль сыграли этнолингвистические теории Н. Я. Марра, постулирующие автохтонность развития этносов. Первая версия национальной истории была подготовлена в 1936 г., но не была опубликована. Она была написана с позиций «школы Покровского», а этногенез азербайджанцев показывался как часть развития тюркских народов. «Большой террор» уничтожил многих авторов первой версии, и на смену им пришли молодые специалисты-«выдвиженцы», преданные партии. Йылмаз подчеркивает их значение в создании новой версии национальных историй. Отталкиваясь от теорий Марра, они связывали азербайджанцев не с тюрками, а с древними мидийцами, тем самым сконструировав уникальную, независимую от Турции и Ирана историческую генеалогию народа. 
Во второй главе The miraculous return of Babak to Azerbaijan ( «Удивительное возвращение Бабека в Азербайджан») исследуется эволюция образа вождя антиарабского восстания IX в. Бабека. Автор показывает, как исторический образ трансформировался в зависимости от контекстов (тюркского, исламского, советского). Советские историки сконструировали образ «народного героя», патриота и борца с иноземными захватчиками. Культ Бабека стал элементом национальной идентичности азербайджанцев не только в советское, но и в постсоветское время.

Следующие две главы посвящены украинской проблематике. В третьей главе Pure Slavic blood for Ukraine («Чистая славянская кровь для Украины») автор утверждает, что в советской историографии доминировала концепция своеобразной этнической чистоты, по которой генезис украинского народа проходил на моноэтничной славянской основе. Необычно, что концепция повторяла теории М. С. Грушевского, к тому времени прочно ассоциировавшегося с «буржуазно-националистической» традицией. Развитие этой концепции Йлмаз объясняет идеологическим противостоянием с немецкими историками, которые подвергли украинцев (так же, как и русских) «ориентализации», доказывая их «неарийское» финно-татарское происхождение. Отсюда следовал вывод о цивилизирующей миссии немцев. В советской контраргументации большая роль отводилась трипольской археологической культуре, располагавшейся на территории современной Украины. Тем самым Украина объявлялась крупнейшим центром цивилизации в древнейшие времена, а трипольцы - прямыми предками славян, что опровергало утверждение нацистских историков о пришлости украинцев и их низком культурном уровне.

Четвертая глава - The adventurous lives of Bohdan Khmel'nyts'kyi («Необычные жизни Богдана Хмельницкого») - посвящена трансформации образа руководителя казацкого антипольского движения середины XVII в. В 1920-е гг. советские историки трактовали фигуру Хмельницкого как представителя феодального класса, «предателя» и врага революционного украинского крестьянства. Но традиционный польско-украинский антагонизм, напряженные отношения СССР с Польшей и тот факт, что западноукраинские территории являлись ее частью, стали важнейшим фактором в активном использовании антипольской составляющей в нациестроительстве советской Украины. В обобщающем издании по истории Украины, вышедшем в 1937 г., Хмельницкий уже предстает как национальный герой, поднимавший простых украинцев на борьбу против польских панов. В 1939 г., сразу после захвата Советским Союзом Западной Украины, вышла биография Хмельницкого в серии «Жизнь замечательных людей».

В пятой главе автор The rise of red batyrs in the Kazakh steppe («Возвышение красных батыров в казахской степи») показывает, что конструирование из батыров национальных героев советского Казахстана тесно связано с трактовкой антицаристских движений, возглавляв- 
шихся ими. В 1920-е гг. такие восстания оценивались историками «школы Покровского» и местными националистами как национально-освободительные и антиколониальные. «Большой террор», в ходе которого были репрессированы многие носители описанной трактовки, привел к переформатированию национального нарратива. С конца 1930-х гг. все больше делался акцент на дружбу и классовую солидарность между русским и казахским народами. Проводился своеобразный отбор батыров, которые могли бы вписаться в советский пантеон. Такой фигурой на короткое время стал Кенесары Касымов, возглавлявший антироссийское движение в 1830-1940-х гг. В послевоенное время его признали реакционным деятелем, мешавшим присоединению Казахстана к России и разрушавшим дружбу народов. Именно в советское время был сформирован общеказахский пантеон исторических героев, ставших основой для конструирования казахской идентичности. Забегая вперед, укажу, что эти же мысли и наблюдения развиваются в седьмой главе Kazakh batyrs marching in Stalingrad («Казахские батыры маршируют в Сталинграде»).

Отдельным блоком выделяются главы, освещающие развитие национальных нарративов в годы Великой Отечественной войны. В специальном введении автор подчеркивает сложную структуру советской пропаганды военного времени, в которой переплетались национальные и коммунистические компоненты, объединенные концептом «советский патриотизм».

В шестой главе Soviet and Iranian Azerbaijan at war («Советский и иранский Азербайджан на войне») демонстрируются усиление исторической пропаганды и ее акцент на военных подвигах. Издание вышло в 1946 г. и базировалось на территориальном принципе, то есть историей республики потенциально становилось все, что происходило на ее территории в прошлом. Так, «древними азербайджанцами» стали древние народы Каспия, кавказские албанцы и мидийцы. Подчеркивались дружественные связи между народами советского Кавказа, которые выступали против иноземных завоевателей - римлян и сасанидов. Акцентировались исторические связи с русским народом. Наконец, в издании можно было обнаружить и историю территорий, на тот момент входивших в Иран. По мнению Йылмаза, сделано это было намеренно, поскольку эти земли на тот момент были оккупированы советскими войсками и СССР имел на их счет далеко идущие планы. Вообще, по наблюдениям автора, с 1937 г. в исторических трудах наблюдалось усиливающиеся антиперсидские тенденции.

В последней, восьмой главе Bohdan Khmelnyts'kyi fighting aganst the Germans («Богдан Хмельницкий сражается против германцев») отмечено, что в военные годы советская историческая идеология столкнулась не только с немецкой пропагандой, но и со стремлением украинских националистов использовать историю в борьбе с советской властью. Так же как и в случае с Азербайджаном, исследователь приходит к выводу, что советская версия украинской истории была 
сконструирована после 1937 г. и комбинировала национально-романтический и классовый компоненты, а в общесоветский пантеон выдающихся исторических фигур были включены Даниил Галицкий и Богдан Хмельницкий, символизирующие единство Западной и Восточной Украины.

Обобщая сказанное, Х. Йылмаз выражает мысль о том, что национальные истории создавались не по единому шаблону. Истории писались в основном местными историками под контролем местных элит, которые принимали самое деятельное участие в нациестроительстве. В этом смысле национальные истории являлись проектами элит, пришедших к власти в 1930-е гг., зачастую в результате Большого террора.

Мобилизация значительного круга опубликованных и архивных документов делает основу выводов убедительной. Однако книга оставляет ряд важных вопросов. Ради детальной проработки отдельных сюжетов автор в значительной степени отказался от анализа советского национального исторического нарратива как целого. Используется понятие «национальные нарративы», что допустимо в тех случаях, когда речь идет об этноцентричных конструкциях. Советские исторические нарративы, которые строились по территориальному принципу, корректнее называть республиканскими, так как они охватывали историю не отдельных этносов, а вбирали в себя прошлое самых значимых народов республики. И главное - акцентируя внимание на внешних факторах в формировании исторических нарративов, автор принижает значение факторов внутриреспубликанских и внутрисоюзных. Например, процесс написания истории Казахстана сложно понять без учета соперничества среднеазиатских партийных элит (включая казахстанскую) за политический капитал внутри республики и на общесоюзном уровне. В частности, оценка восстания 1916 г. в Туркестане (сюжет, который, к сожалению, отсутствует в книге) упиралась в том числе и в соперничество за «присвоение» данного события, когда представители разных кругов выясняли, кто внес больший вклад в восстание, где восстание носило прогрессивный характер, а где лидерство захватили «феодальные элементы». Необходим более подробный анализ диалога между столичными историками и их республиканскими коллегами. Ведь именно на этих встречах вырабатывались различные концепции и проходила их шлифовка.

\section{Список литературы}

Бут Ю. Понятие «нация»: российский и европейский контекст // Quaestio Rossica. T. 5. 2017. № 3. C. 882-892. DOI 10.15826/qr.2017.3.256/

Лінднэр Р. Гісторыкі і ўлада: нацыятворчы працэс і гістарычная палітыка ў Беларусі XIX-XX ст. / пер. з нямецкай мовы Л. Баршчэўскага. СПб. : Неўскі прасцяг, 2005. $540 \mathrm{c}$.

Tillett $L$. The Great Friendship : Soviet Historians on the Non-Russian Nationalities. Chapel-Hill : Univ. of North Carolina Press, 1969. 480 p. 
Yekelchyk S. Stalin's Empire of Memory : Russian-Ukrainian Relations in the Soviet Historical Imagination. Toronto : Univ. of Toronto Press, 2004. 252 p.

\section{References}

But, Yu. (2017). Ponyatie "naciya": rossijskij $i$ evropejskij kontekst [The Concept of Nation: Russian and European context]. In Quaestio Rossica. Vol. 5, № 3. P. 882-892. DOI 10.15826/qr.2017.3.256/

Lidner, R. (2003). Gistoryki i ulada: natsyyatvorchy pratses $i$ gistarychnaya palityka $u$ Belarusi XIX-XX st. [Historians and Power: The Process of Nation-building and Historical Policy in Belarus, $19^{\text {th }}-20^{\text {th }}$ Centuries] / transl. by L. Barshcheusky. St Petersburg, Neuski prastsyag. $540 \mathrm{p}$.

Tillett, L. (1969). The Great Friendship: Soviet Historians on the Non-Russian Nationalities. Chapel-Hill, Univ. of North Carolina Press. 480 p.

Yekelchyk, S. (2004). Stalin's Empire of Memory: Russian-Ukrainian Relations in the Soviet Historical Imagination. Toronto, Univ. of Toronto Press. 252 p.

The article was submitted on 17.05.2018 